PAEDAGOGiA ChRISTIANA

$1 / 23(2009)$ - ISSN 1505-6872

Anna Sokolnicka*

Toruń

\title{
Edukacja jako przestrzeń rozwoju podmiotowości jednostki
}

Zadaniem uniwersytetu jest także uczyć, ale w gruncie rzeczy jest on po to, żeby człowiek, który do niego przychodzi [...] nauczył się myśleć sam.

(Jan Paweł II, Częstochowa 1979 r.)

„Zadaniem uniwersytetu jest t a k ż e uczyć” - te słowa Jana Pawła II skierowane do profesorów i studentów Katolickiego Uniwersytetu Lubelskiego brzmią z pozoru paradoksalnie. $W$ powszechnym odbiorze uczelnia wyższa kojarzy się przede wszystkim z miejscem kontynuowania edukacji, zdobywania wyższego wykształcenia, dyplomu, a wszystko to na drodze przyswajania coraz to nowych zasobów wiedzy. Tymczasem, jak mówi Papież, uniwersytet powinien być raczej miejscem wyzwalania duchowego i umysłowego potencjału człowieka, miejscem w y z w a l a n i a s i ę w najbardziej osobowym akcie ${ }^{1}$. Nie tak istotny jest zatem zasób reguł i twierdzeń, teorii i definicji, z którymi student opuści progi szacownej Alma Mater, ile raczej to, kim wtedy będzie, jakim będzie człowiekiem. Nawiązując do Ericha Fromma można by powiedzieć, że nie chodzi tu o to, by więcej m i é (nie tylko w sensie materialnym, lecz także intelektualnym), ale o to, by bardziej b y ć - by bardziej być człowiekiem². Kluczową rolę edukacji w procesie samorozwoju jednostki dostrzegał już w latach 70. Edgar Faure 3 . We współczesnej rzeczywistości edukacyjnej, funkcjonującej coraz powszechniej na zasadach rynku usług oświatowych, często przedkłada się jednak m i e ć ponad

\footnotetext{
* Mgr Anna Sokolnicka, absolwentka Wydziału Prawa i Administracji oraz Wydziału Nauk Pedagogicznych UMK w Toruniu.

${ }^{1}$ Jan Paweł II, Przemówienie do profesorów i studentów KUL, Częstochowa 1979.

${ }^{2}$ Por. E. Fromm, Duchowe podstawy nowego spoleczeństwa. Mieć czy Być, Warszawa 1968.

${ }^{3}$ E. Faure, E. Herrera, A. R. Kaddoura, H. Lopes, A. W. Pietrowski, W. Rahnema, F. C. Ward, Uczyć się, aby być, Warszawa 1975.
} 
b y ć. Studenci nierzadko ograniczają swoją rolę do tzw. biorców dyplomów, a profesorowie spełniają się $\mathrm{w}$ roli usługodawców ${ }^{4}$. I obie strony bardzo wiele na tym tracą. Universitas powinna być przecież wspólnotą ludzi poszukujących prawdy, odkrywających razem nowe drogi, problemy i ich rozwiązania, wzajemnie się budujących, ubogacających $w$ interpersonalnych relacjach. Tylko wtedy możliwa jest realizacja ideału, który Fromm nazwał mianem homo universalis człowieka w perspektywie pełni człowieczeństwa. Uniwersytet powinien zatem tworzyć „,wspólnotę bycia”s.

\section{Uczyć się, aby być}

Na szczęście wiele jest w uniwersyteckiej rzeczywistości także owych wysepek bycia, gdzie zamiast na wskroś barbarzyńskiego prawa $3 \times Z$ (zakuć, zdać, zapomnieć) liczy się coś więcej - myślenie, samodzielność, autorefleksja. Ogromna tu rola wykładowców. Jednakże dobry wykład stwarza jedynie szansę, możliwość odkrywania i rozwijania potencjału każdego człowieka. Owo stawanie się jest bowiem zadaniem na wskroś indywidualnym, którego nikt za nas wypełnić nie może. Wspólnota, universitas, jest tu wprawdzie warunkiem sine qua non, jednakże autokreacja zakłada już jedynie własną aktywność podmiotu, aktywność, poprzez którą osoba tworzy samą siebie.

Ciekawie ujmuje tę kwestię Karol Wojtyła, rozwijając koncepcję antropogenetycznego wymiaru ludzkiej sprawczości. Jednakże antropogeneza poprzez czyny jest rozumiana nie jako tworzenie człowieka (esse), lecz jako rozwój już istniejącego bytu $(\text { fieri })^{6}$. Człowiek ma zawsze pierwszeństwo wobec działania (praxis). Pierwszeństwo to ma dwa wymiary - metafizyczny i prakseologiczny. W ujęciu ontologicznym pierwszeństwo oznacza afirmację bytu-podmiotu działania jako przyczyny sprawczej, a działania jako przejawu bytu. Pierwszeństwo prakseologiczne oznacza natomiast, że poprzez działanie człowiek tworzy samego siebie ${ }^{7}$. W tym kontekście Karol Wojtyła, nawiązując do Tomasza z Akwinu, określa każde ludzkie działanie jako przechodnie i nieprzechodnie zarazem. P r z e c h o d n i o ść oznacza wykraczanie poza podmiot, dokonywanie zmian w otaczającym świecie. N i e p r z e c h o d n i oś ć natomiast to pozostawanie działania w podmiocie sprawczym, tworzenie w nim nowej jakości i wartości. $\mathrm{W}$ ten sposób aktywność jest zawsze wpisana w określoną płaszczyznę aksjologiczną. „Wartości moralne - dobro i zło - stanowią nie tylko wewnętrzną właści-

${ }^{4}$ Szerzej na ten temat: J. Mikułowski-Pomorski, Uniwersytet wobec zmiany społecznej, w: J. Brzeziński, L. Witkowski (red.), Edukacja wobec zmiany społecznej, Poznań-Toruń 1994, s. 56 i n.

${ }^{5}$ Tamże, s. 77.

${ }^{6}$ K. Wojtyła, Osoba i czyn, Lublin 2000, s. 100 i n.

${ }^{7}$ Tamże, s. 516. 
wość ludzkich czynów, ale mają również to do siebie, że człowiek właśnie jako osoba poprzez te moralnie dobre lub złe czyny sam staje się dobry lub zły".

Każde działanie aktualizuje istotę danego bytu - „to, czym on jest w możliwości, staje się rzeczywistością". I właśnie owa realizacja potencjalnych możliwości jest jednocześnie celem człowieka. Nasuwa się skojarzenie z koncepcją ontologiczną Arystotelesa. Stagiryta charakteryzował wszak byt poprzez rozróżnienie formy i materii oraz ich atrybutów - energii i potencji. Aktywność, energia była tego bytu istota - ,jest” to nie znaczy ,zajmuje przestrzeń”, lecz znaczy „działa"10. Potencja zaś stanowiła uzupełnienie energii i oznaczała określoną możność, dyspozycję do osiagnięcia pełni bycia sobą. Wyznaczała cel w ukierunkowanym rozwoju każdego bytu. Nie była to jednak koncepcja deterministyczna, ponieważ byt mógł, ale nie musiał dojść do pełni swego istnienia. Jego energia, a tym samym potencja, mogła zostać zablokowana na skutek działań zewnętrznych lub zaniechań własnych (w przypadku bytów rozumnych).

Tak więc jest może się redukować do zaj m uj e mi ej s c e. Człowiek jako osoba wolna może zaniechać wszelkich działań rozwojowych i zrezygnować z trudu samodoskonalenia. Może to zrobić, jeśli nie będzie widział w nich żadnego sensu, żadnej korzyści, jeśli ulegnie ułudzie samozadowolenia. W tym kontekście Jose Ortega y Gasset w książce Bunt mas wskazuje, że masowość, jakkolwiek brzmi to paradoksalnie, może być także cechą jednostki ${ }^{11}$. Polega ona wtedy na zadowoleniu z samego siebie, które w prostej linii prowadzi do bierności. Po cóż bowiem podejmować wysiłek bycia kimś innym, gdy brak nam złego o sobie mniemania? Potrzebę takiej autorefleksji dostrzega w swoim wierszu Wisława Szymborska pisząc, że ,nic bardziej zwierzęcego niż czyste sumienie na trzeciej planecie od Słońca"12. To przecież właśnie refleksyjność uchodziła od wieków za atrybut immanentnie ludzki (wskazywali na to chociażby św. Augustyn, Kartezjusz czy Pascal).

\section{Dialog z różnicą}

„Cóż mi po kimś, kto myśli tak samo jak ja?” - pytał retorycznie Michał Bachtin. Myśl ta idealnie oddaje rzeczywistość relacji wychowawczych i edukacyjnych. Dopiero zderzenie z różnicą daje szansę odkrycia czegoś nowego. Jak pisze L. Witkowski, to właśnie „kontakt z innością ma być życiodajny, kulturowo

${ }^{8}$ Tamże, s. 61.

${ }^{9}$ K. Wojtyła, Elementarz etyczny, Wrocław 2000, s. 36.

${ }^{10}$ W. Tatarkiewicz, Historia filozofii, t. 1, Warszawa 2004, s. 113.

${ }^{11}$ J. Ortega y Gasset, Bunt mas, Warszawa 2008, s. 35-37.

${ }^{12}$ W. Szymborska, Pochwała złego o sobie mniemania, w: W. Szymborska, Wiersze wybrane, Kraków 2000, s. 229. 
wzbogacający"13. Tylko różnica może być źródłem rzeczywistego dialogu, który niekoniecznie prowadzić musi do konsensusu, ponieważ właśnie w owej różnicy tkwi jego wartość pedagogiczna ${ }^{14}$. W podobnym duchu wypowiadał się również Jan Paweł II, którego otwartość w podejmowaniu rozmów z przedstawicielami innych wyznań chrześcijańskich oraz innych religii, ze światem kultury i nauki, z politykami i dziennikarzami oraz z przedstawicielami różnorodnych grup społecznych stała się jedną z najbardziej charakterystycznych cech jego pontyfikatu $^{15}$. Jednym z warunków rzeczywistego dialogu jest w przekonaniu Papieża identyfikacja różnic pomiędzy jego uczestnikami. Poznanie i akceptacja różnic nie wymaga jednak bynajmniej rezygnacji z własnych ugruntowanych przekonań któregokolwiek z partnerów interakcji w imię budowania chwiejnego kompromisu. Dialog ma być poszukiwaniem tego, co jest i pozostaje ludziom wspólne, nawet w sytuacji napięcia, sporów, konfliktów ${ }^{16}$.

Dialog zakłada translokację, przemieszczenie, decentrację, stwarzając w ten sposób miejsce dla kultury. Idąc tokiem myślenia J. Derridy czy M. Bachtina, przyjdzie nam skonstatować, że kultura tworzy się właśnie w owej przestrzeni zdecentrowanej, przestrzeni pogranicza, żyje w miejscach nasyconych różnicą. Przyzwolenie na różnice generuje rozwój. Dominacja jest zawsze redukcją.

Ideologia postmodernizmu w odpowiedzi na postulat decentracji proponuje realizację p edagogi i pograni c za ${ }^{17}$. Procesy pedagogiczne stanowić powinny formę przekraczania granic rozumianych jako przejaw społecznych, kulturowych i epistemologicznych ograniczeń stworzonych w duchu modernizmu dla utrzymania władzy. Edukacja i wychowanie muszą prowadzić do t r a n s g r e s j i - procesu, w którym dotychczasowe ograniczenia traktowane będą jak wyzwania i przekraczane oraz definiowane. W ten sposób możliwe stanie się tworzenie pograniczy (borderlands), czyli miejsc, w których, jak pisze Henry Giroux, rozmaite bogactwa kulturowe pozwalają na modelowanie nowych tożsamości w ramach istniejących konfiguracji władzy ${ }^{18}$. Dzięki temu możliwe stanie się wprowadzenie w miejsce normalizacyjnego ignorowania różnic oraz treningu milczenia takich zmian, jak dostrzeganie i akceptowanie różnic społecznych, dopuszczenie różnorodności wypowiedzi czy wreszcie empowerment

${ }^{13}$ L. Witkowski, Decentracyjne dylematy w edukacji, w: J. Garniewicz (red.), Stare i nowe dylematy teorii wychowania. Materiaty z konferencji naukowej, Toruń 1992, s. 16.

${ }^{14}$ J. Rutkowiak, Nauczyciel i Inny: dialog pedagogiczny a zagadnienie różnicy, w: J. Brzeziński, L. Witkowski (red.), dz. cyt., s. 473.

${ }^{15}$ A. Szostek, Jan Pawet II i dialog, w: Colloquia Torunensia IX: Dialog w nauczaniu Ojca Świętego Jana Pawła II, Toruń 2006, s. 13.

${ }^{16}$ Tamże, s. 17.

${ }^{17}$ H. Giroux, Pedagogia pogranicza w wieku postmodernizmu, w: Z. Kwieciński, L. Witkowski (red.), Spory o edukację. Dylematy i kontrowersje we współczesnych pedagogiach, Warszawa 1993, s. 144.

${ }^{18}$ Tamże, s. 145. 
- upełnomocnienie jednostek do aktywnego działania na rzecz swoich racji, na rzecz zmiany nieakceptowanych form dominacji ${ }^{19}$.

\section{Ku autonomii podmiotu}

Działania pedagogiczne nie mogą sprowadzać się jedynie do socjalizacji rozumianej jako ujednolicanie, usuwanie sprzeczności. Istotną rolą edukacji jest przecież także wyzwalanie (liberation). Jak pisze Richard Rorty, chodzi tu o „wyzwalanie ludzi od dominacji ich rodziców, od środowiska i tradycji, w których wyrastali, poprzez wyzwalanie ich wyobraźni - aby umożliwić im zwrócenie się ku jakościowo nowym praktykom społecznym, jakościowo nowym formom życia, nowym sposobom istnienia ludzkiego"20. Edukacja musi przygotowywać jednostkę do aktywnego i świadomego uczestnictwa w złożonej rzeczywistości, do dostrzegania różnorodności świata. Jedną z właściwych ku temu dróg może być pedagogiczna strategia empowerment - upełnomocnienia jednostki, kształtowania w niej poczucia sprawstwa i wewnątrzsterowności, przywracania wiary we własne siły, ukazywania możliwości rozwoju ${ }^{21}$. Chodzi tu o tworzenie optymalnych warunków, w których osoba może podejmować autonomiczne i świadome decyzje odnośnie do własnego życia.

By sprostać temu zadaniu, pedagogika musi, jak zauważa Bogdan Suchodolski, przezwyciężać koncepcję świata gotowego na rzecz otwarcia się ku światu, który powstaje ${ }^{22}$. Tym samym niezbędną kategorią w pedagogice staje się dwoistość, ambiwalencja, niejednoznaczność - tak na poziomie pytań, jak i możliwych na nie odpowiedzi ${ }^{23}$. Należy podkreślić, że nie chodzi tu o przyjęcie relatywizmu wartości i odrzucenie możliwości istnienia fundamentalnych prawd obiektywnych. Istotne jest jednak, aby wybór określonego dobra, normy, zasady był wyborem świadomym i autonomicznym, nie zaś bezrefleksyjnym przyjęciem tego, co zastane lub, co gorsza, narzucone. Ambiwalencja jest cechą współczesnej rzeczywistości, która niesie ze sobą zarówno szanse, jak i zagrożenia, możliwości i bezradność, które nie wykluczają się wzajemnie, lecz przeciwnie współistnieją stanowiąc wyzwanie dla uwikłanego wśród nich człowieka. Także w obrębie ról społecznych mamy do czynienia z parami zaprzeczających sobie norm, jednocześnie domagających się respektowania. Robert Merton w książce Sociological Ambivalence z 1976 roku analizuje ambiwalencję w kontekście ról

${ }^{19}$ T. Szkudlarek, Pedagogika krytyczna, w: Z. Kwieciński, B. Śliwerski (red.), Pedagogika. Podręcznik akademicki, t. 1, Warszawa 2004, s. 370 i n.

${ }^{20}$ R. Rorty, Edukacja i wyzwanie postnowoczesności, w: Z. Kwieciński, L. Witkowski (red.) dz. cyt., s. 96.

${ }^{21}$ N. Herriger, Empowerment in der Sozialen Arbeit, Stuttgart-Berlin-Köln 2002, s. 18.

${ }^{22}$ Por. L. Witkowski, Dwoistość w pedagogice Bohdana Suchodolskiego, Kraków 2001, s. 99 i n.

${ }^{23}$ Tamże, s. 17 i n. 
społecznych (naukowca, lekarza, przywódcy). Każdy z nas jest jednocześnie uwikłany w różne grupy odniesienia, ma różne statusy, gra różne (często sprzeczne) role $^{24}$. Merton akcentuje zwłaszcza te sytuacje, kiedy sprzeczność i niedostosowanie (incompatibility), którym musimy sprostać, realizują się w obrębie jednej $i$ tej samej roli. Tym samym cechy dominujące nie dają wystarczającego obrazu socjologicznego roli. Kluczem do jej zrozumienia staje się właśnie uwypuklenie ambiwalencji, wzajemnie sprzecznych oczekiwań normatywnych. Każda z ról zawiera $\mathrm{w}$ sobie pozostające $\mathrm{w}$ dynamicznej relacji dominujące normy i drugoplanowe (co nie znaczy - mniej ważne) kontrnormy, które często wymagają dopiero odkrycia. Ideał jest zawsze oksymoroniczny - w przeciwnym razie byłby spłycony. Żadna z norm nie może być maksymalizowana kosztem drugiej, gdyż obie są jednakowo ważne. Merton, w przeciwieństwie do Arystotelesa, wyklucza istnienie złotego środka. Zamiast tego wprowadza pojęcie zdystansowanej wrażliwości (detached concern) ${ }^{25}$ rozumianej jako umiejętność oscylowania, naprzemienne dochowywanie wierności normom, stanowiące warunek właściwego wypełnienia roli społecznej. Nie ma tu jednej gotowej recepty. Każdy sam musi zmierzyć się z tym dylematem.

\section{Pedagog wobec ambiwalencji norm}

Istotne pedagogicznie jest przeniesienie koncepcji Mertona na grunt socjologii edukacji i uchwycenie w kontekście tych analiz roli nauczyciela-wychowawcy. Tu także mamy do czynienia z koniecznością oscylowania pomiędzy normami i kontrnormami: z jednej strony bliskość, serdeczność, z drugiej - potrzeba zdystansowania. Dostrzeganie tej ambiwalencji implikuje określone postulaty praktyczne, umożliwiające przeciwdziałanie odrzuceniu nauczyciela nawet w sytuacji jego pełnego zaangażowania. Lech Witkowski wskazuje, że to „właśnie kompetencja do zachowania niezredukowanej ambiwalencji w roli nauczyciela jest warunkiem tego, że nauczyciel da sobie radę w każdej sytuacji, tzn. będzie empatyczny, gdy to będzie niezbędne, ale potrafi być też twardy i zdystansowany, by wyzwolić koncentrację uwagi i motywację do wytrwałości, dyscypliny, wysiłku"26.

W działaniach edukacyjnych pedagog ma do wyboru cztery estetyki określające formę podejmowanej przez niego aktywności ${ }^{27}$. Pierwsza z nich to nakaz bycia „Tym Pierwszym”. W świetle tej estetyki pedagog ma zawsze rację i od

${ }^{24}$ L. Witkowski, Ambiwalencja jako kategoria socjologii edukacji, w: J. Brzeziński, L. Witkowski (red.), dz. cyt., s. 195 i n.

${ }^{25}$ Tamże, s. 196.

${ }^{26}$ Tamże, s. 198.

${ }^{27}$ L. Witkowski, Cztery estetyki sytuacji edukacyjnych. W stronę pedagogiki ambiwalencji, w: tenże, Edukacja wobec sporów i (po)nowoczesność, Warszawa 1997, s. 216-232. 
niego wszystko zależy, ponieważ dysponuje władzą. Druga estetyka zakłada bycie „Tym Drugim” - znaczącym Innym, autorytetem. Tu nie wystarczy już władza - potrzebna jest osobowość. Trzecia estetyka pedagogiczna oznacza bycie „Tym Trzecim” - mediatorem, katalizatorem, tłumaczem. Aby wejść w tę rolę, trzeba umieć ograniczać własne roszczenia, by móc przywołać cudze myślenie, stać się pomostem. Czwarta estetyka, to zasada bycia „Tym Czwartym”. Prowadzi do stawania się uczestnikiem w sytuacji, w której pozostali ćwiczą umiejętność współdziałania. To bycie partnerem na tych samych prawach, bez asymetrii pozycji. Istnieje także piąta estetyka - bodaj najistotniejsza. Zakłada ona oscylację pomiędzy opisanymi wyżej modelami. Trafny wybór działania w konkretnej sytuacji edukacyjnej nie jest łatwy, jest sztuka, ale jest jednocześnie niezwykle istotny. Błąd estetyczny może się bowiem okazać błędem etycznym, który zniweczy całą relację wychowawczą.

Pedagog musi umieć przekraczać pozorną jednoznaczność rzeczywistości, która zwykle bywa jedynie piękną przykrywką dla przemocy symbolicznej. Istotne jest zachowanie postawy czujności i refleksyjności w stosunku do innych, ale przede wszystkim do siebie. Gombrowicz pisał, że „ten, kto uwierzył we własną autentyczność, stracił szansę nań”. Musimy nieustannie siebie poznawać. W przeciwnym razie, sądząc że wiemy o sobie wszystko, tak naprawdę będziemy tkwić w głębokiej niewiedzy. Autentyczność wymaga respektowania dwoiście zorientowanych konieczności, jednoczesnego przestrzegania i przekraczania formy. Jeżeli zapomnimy o założonej masce, przyrośnie nam ona do twarzy, gdy tymczasem pierwszą moralną powinnością człowieka jest bycie sobą. Jest to powinność niezwykle trudna do realizacji, a największa trudność nie wynika bynajmniej z presji społecznej - choć tak zwykle sądzimy. O wiele groźniejsza jest deformacja wewnętrzna, efekt samozadowolenia, niestawianie sobie wymagań. Należy także uważać, aby uzyskiwanie samowiedzy nie odbywało się drogą testowania odporności, stosowania strategii inwazyjnej. W ten bowiem sposób wystawiamy na szwank nie tylko samych siebie, lecz także drugiego człowieka, tracąc tym samym szansę na dialog z innością.

\section{Dać sobie powiedzieć}

Tymczasem dialog stanowić powinien podstawową kategorię współczesnej pedagogiki, prowadzaca poprzez relacje interpersonalne do podtrzymywania różnicy. Jak bowiem wskazuje Gadamer, istotą dialogu jest dostrzeżenie w nim inności jako szansy dla siebie. Nie wystarczy tylko c h c i e ć p o w i e d z i e ć - trzeba sobie d a ć p o w i e d z i e ć, co wcale nie oznacza, by dać się przekonać. Aby komunikacja mogła być skuteczna, konieczne jest przestrzeganie pewnych obowiazzujących w interakcjach społecznych warunków porozumiewania się. Jürgen Habermas wskazuje, że nawet nic nie mówiąc, można zakłócić komunikację. Co zatem robić, aby do tego nie doszło? Konieczne jest postępowanie 
zgodne z pewną założoną konwencją i respektowanie wynikających z niej normatywnych zobowiązań, które Habermas nazywa ro s z c z e n i a m i w a ż n o ś c i (Geltungsansprüche) ${ }^{28}$. Owe roszczenia składają się na swego rodzaju uniwersalną gramatykę porozumiewania się ludzi, budując swoistą etykę mowy. W tym sensie każdy akt mowy powinien zaspokajać cztery główne roszczenia: roszczenie zrozumiałości, prawdziwości, szczerości i słuszności. Zaspokojenie wszystkich czterech roszczeń stwarza idealną formę porozumiewania się. Rygorystyczne przestrzeganie powyższych reguł może się jednak okazać problematyczne w konkretnej sytuacji dialogowej. Habermas dopuszcza w takim wypadku próbę wzajemnego uzgodnienia roszczeń. Komunikacja przybiera wówczas formę dyskursu, którego przedmiotem mogą być albo problematyczne twierdzenia (dyskurs teoretyczny), albo problematyczne normy (dyskurs praktyczny) ${ }^{29}$. Aby nie być jedynie grą pozorów, dyskurs powinien także spełniać określone warunki. „Mówiąc najogólniej, powinien on przede wszystkim umożliwiać komunikację wolną od wszelkich nacisków i przymusów, zapewniać swobodę krytyki i rewizji wszystkich założeń, a tym samym wykluczać wszelkie formy zniekształconej komunikacji" "30. Istotą komunikacji musi być postawa konsensualna, zorientowana na dojście do porozumienia. Odpowiedzialność za jakość dialogu spoczywa nie tylko na nadawcy komunikatu, lecz także na jego odbiorcy. To właśnie odbiorca powinien w odpowiednim momencie upomnieć się o siebie, sygnalizując niespełnienie określonego roszczenia. W przeciwnym wypadku dialog zostanie zafałszowany, a tym samym rzeczywista komunikacja nie dojdzie do skutku.

\section{Stawiać pytania}

Włączanie w narrację troski o roszczenia zakłada refleksyjność partnerów interakcji. Konieczne jest wyzbycie się schematów i odwaga myślenia (sapere aude!). Cogito ergo sum - stwierdził Kartezjusz, przyznając tym samym rację świętemu Augustynowi. Myślenie jest atrybutem właściwym jedynie istotom

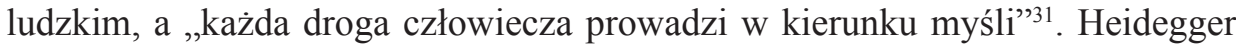
wskazuje jednak, że nie zawsze to, co nazywamy myśleniem, jest nim w istocie. Prawdziwe myślenie jest zarazem n a m y s ł e m, odracza odpowiedź, jest przyglądaniem się pytaniu, badaniem jego ewentualnych pułapek, sięganiem do źródła, do którego trzeba przedzierać się pod prąd. Nie można być zakładnikiem

${ }^{28}$ L. Morawski, Dyskurs w ujęciu Jürgena Habermasa a inne koncepcje argumentacji, w: L. Witkowski (red.), Dyskursy rozumu: między przemocq i emancypacja. Z recepcji Jürgena Habermasa $w$ Polsce, Toruń 1990, s. 124.

${ }^{29}$ Tamże, s. 125.

30 Tamże.

${ }^{31}$ K. Wojtyła, Szymon z Cyreny, w: K. Wojtyła, Pieśń o Bogu ukrytym - poezje, Warszawa 1998 , s. 115. 
tego, co uchodzi za normę - tego, co s i ę mówi, s i ę czyta, s i ę robi. To „s i ę” eliminuje w istocie nasze myślenie. Myśleć bowiem, to nie tyle oczekiwać odpowiedzi, ile stawiać pytania. Cała historia filozofii zaczęła się przecież w momencie, gdy pewien mieszkaniec Miletu stwierdził, że mity i wierzenia nie są wystarczającym wyjaśnieniem złożoności świata i... postawił pytanie, które okazało się stokroć ważniejsze od odpowiedzi. „Jeżeli w czym leżała zasługa Talesa, to w postawieniu pytania, a nie w odpowiedzi, jaką nań dał"32. Właśnie pytanie przyniosło temu na wpół legendarnemu Grekowi zaszczytne miano ojca filozofii.

Jednym z kluczowych pytań w kontekście pedagogiki oraz innych nauk humanistyczno-społecznych jest pytanie o tożsamość w odniesieniu do jednostek, grup społecznych, instytucji, które ogólnie określić można mianem systemów. Tożsamość jest odpowiedzią na pytanie „kim jestem?” bądź „kim jesteśmy?” Charakteryzuje ona pewien typ rozwiązań problemów, jakie podejmuje podmiot na danym etapie swojego rozwoju, pewien zakres zdolności działania. Erikson określał tożsamość jako „styl syntezy doświadczenia”33. Zgodnie z koncepcją Habermasa, funkcjonowanie tożsamości rozpatrywać można w trzech poziomach odpowiadających trzem strukturom złożoności świata działań. Zróżnicowanie to następuje ze względu na możliwe odniesienia działań jednostek (systemów) odpowiednio do behawioralnie pojmowanych skutków działań - efektów, do elementów kodyfikujących dane działania - norm i reguł czy wreszcie w perspektywie aksjologicznej - w odniesieniu do zasad i wartości ${ }^{34}$. W tym sensie pierwszym wariantem złożoności świata jest model pła s k i, w którym cała rzeczywistość zlewa się do poziomu efektów. Mamy tu więc do czynienia ze stanem anomii. Drugim wariantem jest świat j e d n o p i ę t r o w y, który dopuszcza już odniesienie działań do poziomu normatywnego, jednak bez możliwości kwestionowania wartości reguł i norm. Ostatnim wariantem świata jest struktura d w u p i ę t r o w a , w której możliwa staje się ocena działań w kontekście aksjologicznym. Te trzy płaszczyzny świata działań charakteryzują kolejne stadia dojrzałości moralnej człowieka (przedkonwencjonalny, konwencjonalny i postkonwencjonalny), wyznaczając tym samym trzy hierarchicznie usytuowane typy tożsamości - tożsamość n a t u r a 1 n ą, tożsamość r o 1 i i tożsamość e g o (poziom autonomii) ${ }^{35}$. Osiagnięcie poziomu autonomii zakłada przejście przez poprzednie etapy. W praktyce niewielu ludzi osiaga to najwyższe stadium. Dotyczy to także nauczycieli, co stanowi swoisty paradoks, jako że ich zadaniem jest przecież stymulowanie rozwoju wychowanków.

Podsumowując należy podkreślić, jak wielką rolę ma do spełnienia edukacja w zakresie tworzenia przestrzeni sprzyjającej budowaniu podmiotowości jed-

${ }^{32}$ W. Tatarkiewicz, dz. cyt., s. 26.

${ }^{33}$ L. Witkowski, Problem uniwersalizacji tożsamości. Habermas - Kohlberg - Erikson, w: tenże (red.), Dyskursy, s. 273.

${ }^{34}$ Tamże, s. 276 i n.

${ }^{35}$ Tamże, s. 278. 
nostki. Jest to szczególnie istotne w świecie XXI wieku, który tak często stara się sprowadzić człowieka do roli przedmiotu lub co najwyżej konsumenta dóbr albo globalnie ujednoliconych wytworów kultury masowej. Dlatego we współczesnej rzeczywistości edukacyjnej to właśnie humanistycznie pojmowany rozwój stanowić powinien naczelny cel wychowania. Rozwój, który zgodnie z koncepcją progresywistyczna, zakłada sprzyjanie harmonijnemu wzrostowi jednostki we wszystkich płaszczyznach jej egzystencji, wyzwalanie aktywności społecznej, moralnej i intelektualnej poprzez stymulowanie pokonywania kolejnych stadiów i kryzysów. W takim ujęciu wychowanek staje się raczej poszukującym prawdy filozofem niż automatem do przetwarzania kolejnych zasobów wiedzy ${ }^{36}$. Edukacja doby postmodernizmu musi odstapić od tradycyjnego roszczenia do centrum na rzecz odkrycia nowej tożsamości poprzez dekonstrukcję, transgresję i dialog. Także i nauczyciel powinien wyrzec się jednowymiarowości na rzecz otwarcia się na inność, różnicę. Powinien stać się, jak pisze Canetti ${ }^{37}$, strażnikiem przemiany siebie samego. Tylko wówczas zdolny będzie wchodzić w prawdziwe i konstruktywne relacje wychowawcze, będzie zdolny do wyzwalania w wychowankach ich własnej potencji i do wspólnego poszukiwania odpowiedzi na najważniejsze z pytań. Bo przecież nauczyciel, to nie ten, którego m o ż n a pytać, lecz ten, którego pytać w a r to .

\section{Education as the space of individual's personality development (Summary)}

A man in XXI century is too often being made by society just as a consumer of goods and pop-culture. In educational practice there is usually also more important to have than to be. That is why is so necessary to consider the meaning, which education could have today. The author (of this article) thinks, that it should be the space of individual's personality development. For make this situation possible we must respect those pedagogical cathegories like: dialogue, empowerment, sociological ambivalence or borderlands. That is the only way for making education more human and more useful for everyone. Lastly we must notice that in such matter, asking question might be more difficult but also more essential than reply to them.

${ }^{36}$ L. Kohlberg, R. Mayer, Rozwój jako cel wychowania, w: Z. Kwieciński, L. Witkowski (red.) dz. cyt., s. 76 i n.

${ }^{37}$ E. Canetti, Sumienie stów - eseje, Kraków 1999, s. 23. 